\title{
Wood moisture content variation in white spruce defoliated by spruce budworm
}

\author{
by David W. Ip ${ }^{1}$, Irene L. Pines ${ }^{2}$ and A. Richard Westwood ${ }^{2}$
}

\begin{abstract}
Mature and over mature white spruce [Picea glauca (Moench) Voss] repeatedly defoliated by spruce budworm (Choristoneura fumiferana $\mathrm{Clem}$.) in eastern Manitoba, were investigated for variation in moisture content $(\mathrm{MC})$ which is known to influence pulping quality. In the fall of 1991, 100 trees in the Abitibi-Price Inc. Forest Management Licence area were selected randomly in two size classes and four defoliation classes. Heartwood and sapwood MC (\% dry weight) was measured in 5-cm thick disks cut at 2.5 to $5.0 \mathrm{~m}$ intervals for small and large trees, respectively. Living trees with more sapwood than heartwood had a mean MC of $117 \%$, and those with more heartwood than sapwood had a mean MC of $77 \%$. Both of these groups contained sufficient overall moisture (>45\%) for pulping. The repeated defoliation did not affect the overall $\mathrm{MC}$ in live trees. Mean MC of trees killed by spruce budworm defoliation was $42 \%$ but this level varied with diameter and height above ground: $>45 \%$ in stems greater than $36 \mathrm{~cm}$ diameter inside bark, $30-60 \%$ in sections $17-36 \mathrm{~cm}$, and $<45 \%$ in sections less than $17 \mathrm{~cm}$. A minimum DBH of $30 \mathrm{~cm}$ is suggested as a criterion for accepting dead trees.
\end{abstract}

Key words: insect defoliation impact, wood moisture content, sapwood, heartwood, dead tree fibre, Manitoba
Les épinettes blanches [Picea glauca (Moench) Voss] mûres et surannées, défoliées à répétition par la tordeuse de l'épinette (Choristoneura fumiferana Clem.) dans l'est du Manitoba, ont été étudiées afin de connaitre la variation du contenu en humidité $(\mathrm{CH})$ lequel est reconnu comme ayant une influence sur la qualité de la mise en pâte. Au cours de l'automne de 1991, 100 arbres de la zone forestière sous la responsabilité d'Abitibi-Price ont été choisis au hasard selon deux classes de diamètre et quatre classes de défoliation. Le $\mathrm{CH}$ du bois de coeur et de l'aubier (en \% de masse sèche) a été mesuré sur des disques de $5 \mathrm{~cm}$ d'épaisseur découpés selon des intervalles de 2.5 à $5 \mathrm{~m}$ pour les arbres respectivement de petites et de grandes dimensions. Les arbres vivants ayant plus de bois d'aubier que de bois de coeur avaient un $\mathrm{CH}$ moyen de $117 \%$, et ceux avec plus de bois de coeur que de bois d'aubier avaient un $\mathrm{CH}$ de $77 \%$. Les deux groupes contenaient suffisamment d'humidité de façon globale $(>45 \%)$ pour la mise en pâte. La défoliation à répétition n'a pas affectée le $\mathrm{CH}$ total des arbres vivants. $\mathrm{Le} \mathrm{CH}$ moyen des arbres tués par la défoliation de la tordeuse de l'épinette était de $42 \%$ mais ce niveau variait selon le diamètre et la hauteur au-dessus du sol: $>45 \%$ pour les tiges de plus de $36 \mathrm{~cm}$ de diamètre sous écorce, $30-60 \%$ pour les sections de 17 à $36 \mathrm{~cm}$, et $<45 \%$ pour les sections de moins de $17 \mathrm{~cm}$. Un diamètre minimal de $30 \mathrm{~cm}$ est suggéré en tant que critère d'acceptation des arbres morts.

Mots clés: impact de la défoliation par les insectes, contenu en humidité du bois, aubier, bois de coeur, fibre de bois mort, Manitoba

\section{Introduction}

From 1979 to 1991 , areas up to 66,000 ha of white spruce [Picea glauca (Moench) Voss] and balsam fir [Abies balsamea (L.) Mill.] forest in eastern Manitoba (Lake Winnipeg East) were moderately to severely infested by spruce budworm [Choristoneura fumiferana (Clem.)] (Cerezke and Gates 1992; Moody and Cerezke 1985). The outbreak was first detected in the Abitibi-Price Inc. Forest Management License (Forest Management Unit 31) in 1979, increasing in size and intensity, and peaking in 1984; populations remained high throughout the decade (Knowles et al. 1992). Defoliation declined significantly since 1990 . Salvage wood from insect, blowdown and fire damage comprised 29 and 40\%, in 1989 and 1990 respectively, of the harvest volume ${ }^{3}$. The AbitibiPrice Inc. mill at Pine Falls, Manitoba currently requires a wood MC of approximately $45 \%$ to achieve desired product quality ${ }^{4}$. Preliminary observations in the field and at the mill suggested the MC of budworm-affected spruce was so low it affected pulp quality.

${ }^{1}$ Canadian Forest Service, Natural Resources Canada, 5320 - 122nd St., Edmonton, Alberta, Canada T6H 3S5.

${ }^{2}$ Landscape Management, Forestry Branch, Manitoba Natural Resources, 300-530

Kenaston Blvd., Winnipeg, Manitoba, Canada R3N 1 Z4.

${ }^{3}$ Personal communication. G. Pinnell, Woodlands Manager, Abitibi-Price Inc., Pine Falls Division, Manitoba, 31 May 1991.

${ }^{4}$ Personal communication. T.H. Peacock, Divisional Forester, Abitibi-Price Inc., Pine Falls Division, Manitoba, 5 June 1991.
Moisture content (MC) of green eastern spruce (Picea spp.) averages $34 \%$ in the heartwood and $128 \%$ in the sapwood (Haygreen and Bowyer 1982). As trees age, overall MC generally declines with the declining proportion of sapwood. The impact of insect defoliation on wood MC has not been widely reported. Grammel et al. (1986) found that green sapwood of spruce that had lost $70 \%$ or more of its one- to three-year-old needles due to needle cast showed reduced MC while fir (Abies sp.) under similar conditions did not. Barnes and Sinclair (1983) reported significant differences in MC of balsam fir between sapwood and heartwood of healthy trees versus trees killed by spruce budworm; outer section MC (dry weight) decreased from $155 \%$ in healthy trees to $68 \%$ in trees dead for 12 months; inner section MC decreased from $125 \%$ in healthy to $109 \%$ in trees dead for 12 months.

Decreases or increases in $\mathrm{MC}$ can affect paper brightness, tear factor and processing (Binotto and Locke 1981). Lowery et al. (1977) reported that $30 \%$ more energy was needed to chip dead versus green Engelmann spruce (Picea engelmannii Parry). Moisture content is also an important factor in determining the liquor-to-wood ratio in the pulping digester (Parham 1983). It is more efficient to pulp water-swollen cell walls than those of drier wood because of easier penetration and saturation by the pulping liquor. As the wood dries, pits between the fibres close in, thus restricting free movement of pulping liquor. van Raalte (1983b) reported a one- to five-year 
increase in MC from about $42 \%$ to $65 \%$ wet weight (72\% to $186 \%$ dry weight) of balsam fir associated with budworm kill. The implications of an increase in $\mathrm{MC}$ are greater deterioration due to decay, slower drying rates in piled wood resulting in further deterioration, and increased transportation and purchase costs because of heavier truck loads. In dead timber, MC influences decay rate, fire hazard, and wood loss during skidding and debarking (Basham 1980; Binotto and Locke 1981; Kiil 1968; van Raalte 1983a,b).

This study was initiated to determine the relationship between spruce MC and defoliation by spruce budworm, and to identify the trees expected to have low MC based on pulping requirements.

\section{Methods \\ Study Area}

The study area consisted of five white spruce and white spruceaspen stands on the north side of Bird Lake, Manitoba $\left(50^{\circ} 29^{\prime} \mathrm{N}, 95^{\circ} 17^{\prime} \mathrm{W}\right)$. This area had been heavily infested by spruce budworm and was scheduled to be salvaged during the winter of 1991-1992. All stands were Site Class 1 (Manitoba Natural Resources 1989) and predominantly mature and overmature. Fourteen plots were randomly selected from a grid of $400-\mathrm{m}^{2}$ plots within $72 \mathrm{ha}$. All spruce trees in each plot were sampled. Plots were selected consecutively until there were at least five trees in each defoliation-by-size category.

The sampling population consisted of standing trees, with a minimum diameter at breast height (DBH) of $10 \mathrm{~cm}$, and a top diameter of $7.5 \mathrm{~cm}$. Buffer zone and cull trees were excluded from the sampling population. Budworm-killed trees were included, although these were normally considered unmerchantable. Initially, trees were classed as "small" (DBH $<30 \mathrm{~cm}$ ) or "large" (DBH $\geq 30 \mathrm{~cm}$ ). Defoliation class was estimated according to crown defoliation and likelihood of survival:

\section{Defoliation Class 1: dead trees.}

Defoliation Class 2: severely defoliated, declining, not likely to recover.

Defoliation Class 3: severely defoliated, likely to recover. Defoliation Class 4: lightly or not defoliated.

Dead trees (Class 1) were cut in August 1991 and the live trees were cut in September and October 1991. The trees were felled at an approximate butt height of $30 \mathrm{~cm}$, delimbed and cut into pulp or sawlog lengths $(2.54,3.77,5.08 \mathrm{~m}$ Tolerance level 1) (Canadian Standards Association 1986). A four- to five-cm thick disk was cut from the end of each log including the butt end. Tops above $7.5 \mathrm{~cm}$ diameter, and major stem defects were excluded from sampling. All disks were immediately placed in plastic bags and taken to the mill for weighing. Elapsed time between disk-cutting and weighing averaged four hours. On warm days $\left(>15^{\circ} \mathrm{C}\right)$, disks were carried in an electric cooler to reduce evaporation. One or two sapwood and heartwood samples were cut from each disk and weighed on a microbalance to $\pm 0.5 \mathrm{~g}$ if greater than $22 \mathrm{~g}$, and $\pm 0.1 \mathrm{~g}$ if less than $22 \mathrm{~g}$. Sapwood-heartwood borders were estimated visually by wet and dry appearance (dark-light) of wood. When the border could not be found, as in tree tops and some dead trees, the entire disk was weighed. After drying at $100^{\circ} \mathrm{C}$ for at least 40 hours, the samples were weighed again. Ninety percent of the trees were sampled within one to eight days of felling, and all were sampled within 14 days. Sapwood, heartwood and outside bark diameters were measured to $\pm 0.1 \mathrm{~cm}$. The disks were visually examined for incidence of stain or decay.

\section{Analysis}

The percent $\mathrm{MC}$ by dry weight of the sample blocks was calculated as follows (Parham 1983): $\mathrm{MC}=$ (wet weight - dry weight)/dry weight $\times 100$. The overall MC of each disk was calculated from the weighted means of the heartwood and sapwood subsamples and the heartwood:sapwood disk area ratios. The overall moisture of each tree (inside bark, merchantable portion) was calculated using Smalian's volume formula (Husch et al. 1972) and the weighted averages of the disk MCs. Moisture content $(Y)$ was compared according to defoliation class $(D)$ and size class $(S)$ using the following model:

$Y_{\mathrm{ij}}=D_{\mathrm{i}}+S_{\mathrm{j}}+D S_{\mathrm{ij}}+E_{\mathrm{ij}}$ where error $(E)$ is the variation among trees of the same defoliation-size class, $i$ is any given defoliation class of 1,2 , 3 or 4 , and $j$ is any given size class, small or large.

Heartwood-to-sapwood volume ratio $(\mathrm{H} / \mathrm{S})$ was found to be a much better predictor of $\mathrm{MC}$ in living trees $\left(r^{2}=0.73, n=\right.$ $\left.74\left[(\% \mathrm{MC})^{0.8}=158.9-119.6 \times(\mathrm{H} / \mathrm{S})^{0.1}\right]\right)$ than $\mathrm{DBH}\left(r^{2}=\right.$ 0.08 ). The MC levels could generally be divided into well-defined groups at $\mathrm{H} / \mathrm{S}=1$. Therefore, delimitation based on size was changed from the arbitrary $30-\mathrm{cm} \mathrm{DBH}$ to a $\mathrm{H}: \mathrm{S}$ ratio greater than or less than 1 , which occurred on average at $23 \mathrm{~cm}$ $\mathrm{DBH}$. The delineation between sapwood and heartwood was frequently unclear in dead trees, for which size delimitation was set at $23 \mathrm{~cm}$ DBH for analysis. Bartlett's test for homogeneity was used before conducting analysis of variance (Freese 1967). Data were grouped when differences between classes were insignificant.

\section{Results}

A total of 100 merchantable-size white spruce trees were harvested from the 14 plots. From these trees, 571 disks were cut for analysis. The numbers of trees per defoliationsize treatment combination were uneven. There were very few large Defoliation Class 2 trees in the study area, likely because most died soon after being severely defoliated in 1989 and 1990 and moved into Class 1 .

The sample means and standard deviations in each defoliation-size treatment combination are shown in Table 1. The variances of the actual MCs were homogeneous $(P=0.01$, Bartlett's test). The untransformed means were within 7 to $13 \%$ of the true treatment means [ $95 \%$ confidence interval $(\mathrm{CI})]$. The treatment means were analyzed and compared by two-way ANOVA (Tables 2 and 3 ).

Difference in the MCs in the defoliation classes by large and small trees are given (Fig. 1). All live trees had well over the minimum preferred $45 \% \mathrm{MC}$, regardless of size or defoliation class. There were no differences between defoliation classes in the live trees $(P=0.09$; Bartlett's test $P=0.02)$ (Table 3), thus the live trees were grouped within size categories. Between size classes, those trees with more sapwood than heart$\operatorname{wood}(\mathrm{H} / \mathrm{S}<1.0)$ averaged $117 \% \mathrm{MC}(95 \%$ C.I. of 110 to $127 \%)$ while those with less sapwood than heartwood averaged $77 \%$ ( $95 \%$ CI of 73 to $82 \%$ ) (Table 1). Differences between dead trees and all classes of live trees (pooled variance contrasts $P<<$ 0.01 ; Bartlett's test $P=0.04$ ) are also provided (Fig. 1). The 


\begin{tabular}{ccccc}
\hline \multicolumn{5}{l}{ Table 1. Moisture contents (MC) of defoliated trees } \\
\hline $\begin{array}{c}\text { Defoliation } \\
\text { class }\end{array}$ & $\begin{array}{c}\text { Size } \\
\text { class }\end{array}$ & $\begin{array}{c}\text { Number } \\
\text { of trees }\end{array}$ & $\begin{array}{c}\text { \% MC } \\
\text { Mean }\end{array}$ & SD $^{\mathbf{1}}$ \\
\hline 1 (Dead) & $<23 \mathrm{~cm} \mathrm{DBH}{ }^{2}$ & 17 & 44 & 17 \\
& $>23 \mathrm{~cm} \mathrm{DBH}$ & 10 & 37 & 12 \\
2 & $\leq 1.0 \mathrm{H} / \mathrm{S}^{3}$ & 8 & 119 & 24 \\
& $>1.0 \mathrm{H} / \mathrm{S}$ & 9 & 79 & 13 \\
3 & $\leq 1.0 \mathrm{H} / \mathrm{S}$ & 13 & 124 & 17 \\
& $>1.0 \mathrm{H} / \mathrm{S}$ & 26 & 79 & 14 \\
4 & $\leq 1.0 \mathrm{H} / \mathrm{S}$ & 1 & 105 & 0 \\
& $>1.0 \mathrm{H} / \mathrm{S}$ & 17 & 80 & 16 \\
\hline
\end{tabular}

${ }^{1} \mathrm{SD}=$ standard deviation.

${ }^{2}$ Heartwood/sapwood borders were not always distinct in the dead tree samples; the average DBH at which heartwood volume = sapwood volume in live trees was $23 \mathrm{~cm}$.

${ }^{3} \mathrm{H} / \mathrm{S}$ ratio of heartwood volume to sapwood volume; 1.0 means $50 \%$ heartwood and $50 \%$ sapwood.

Table 2. Analysis of variance of moisture content (MC) in a two-way design for defoliation class (Def) and size of tree (Using SAS software, type III ANOVA)

\begin{tabular}{|c|c|c|c|c|c|}
\hline Source & DF & $\begin{array}{c}\text { ANOVA } \\
\text { sum of } \\
\text { squares }\end{array}$ & $\begin{array}{l}\text { Mean } \\
\text { square }\end{array}$ & $F$ value & $P>F$ \\
\hline \multirow{7}{*}{$\begin{array}{l}\text { Def } \\
\text { Size } \\
\text { Def } \times \text { Size } \\
\text { Model } \\
\text { Error } \\
\text { Corrected } \\
\text { total }\end{array}$} & 3 & 53097.0 & 17699.00 & 63.79 & 0.0001 \\
\hline & 1 & 5290.2 & 5290.22 & 19.07 & 0.0001 \\
\hline & 3 & 19682.7 & 6560.90 & 23.65 & 0.0001 \\
\hline & 7 & 78070.0 & 11152.85 & 40.20 & 0.0001 \\
\hline & 92 & 25526.9 & 277.47 & & \\
\hline & 99 & 103596.9 & & & \\
\hline & & $\begin{array}{r}\boldsymbol{R} \text {-square } \\
0.75\end{array}$ & $\begin{array}{r}\text { Coeff.of } \\
\text { variation } \\
21.21\end{array}$ & $\begin{array}{c}\text { Root mean } \\
\text { squared } \\
\text { error } \\
16.66\end{array}$ & $\begin{array}{c}\text { mean } \\
78.54\end{array}$ \\
\hline
\end{tabular}

MCs of the dead trees were not different between size classes, so all dead trees were grouped together. The grouped MC of the dead class averaged $42 \%$.

The MC in the bottom most logs of 14 of the 17 small dead trees was $>45 \%$. Only one had $>45 \% \mathrm{MC}$ in the first two pulp logs ( $5.0 \mathrm{~m}$ above ground), and none had $>40 \%$ above the second pulp log. In contrast, among the ten larger dead trees, > $23 \mathrm{~cm} \mathrm{DBH}$, three trees had $<32 \% \mathrm{MC}$ even in the bottom most section, while six trees (all $\geq 32 \mathrm{~cm} \mathrm{DBH}$ ) had at least $44 \%$ $\mathrm{MC}$ up to $5 \mathrm{~m}$ above ground and in some as high as $15 \mathrm{~m}$ above ground.

\section{Discussion}

The purpose of this study was to help identify the quality of defoliated spruce timber for pulp processing. In terms of MC, the trees could be divided into three normally distributed groups: (1) dead trees (Defoliation Class 1), regardless of size; (2) live trees (Defoliation classes 2, 3 and 4) with heartwood volume less than sapwood volume; and (3) live trees with heartwood volume greater than sapwood volume. As long as the trees were still alive, the overall $\mathrm{MC}$ of all logs was well over the desired $45 \%$ minimum. Pulp and paper manufacturers should be concerned about the impacts of defoliation of which three are (1) the MC in dead trees; (2) the effect on MC of heartwood:sapwood volume ratio and the height of the log in the tree; and (3) the physical and biological interactions between wood $\mathrm{MC}$ and defoliation.
Table 3. Comparison of means of moisture content in defoliated living white spruce

\begin{tabular}{lllll}
\hline Comparison & F & d.f. & $\mathbf{F}_{\alpha=0.05}$ & Significance \\
\hline $\begin{array}{l}\text { Small vs. Large } \\
(\mathrm{H} / \mathrm{S}<1 \text { vs. H/S }>1)\end{array}$ & 1.660 & 5,66 & 2.36 & none \\
$\begin{array}{l}\text { Def. Class } 2 \text { vs. } 3 \\
\text { vs. } 4(\mathrm{H} / \mathrm{S}<1)\end{array}$ & 0.125 & 2,22 & 3.44 & none \\
$\begin{array}{l}\text { Def Class } 2 \text { vs. } 3 \\
\text { vs. } 4(\mathrm{H} / \mathrm{S}>1)\end{array}$ & 0.030 & 2,44 & 3.21 & none \\
\hline
\end{tabular}

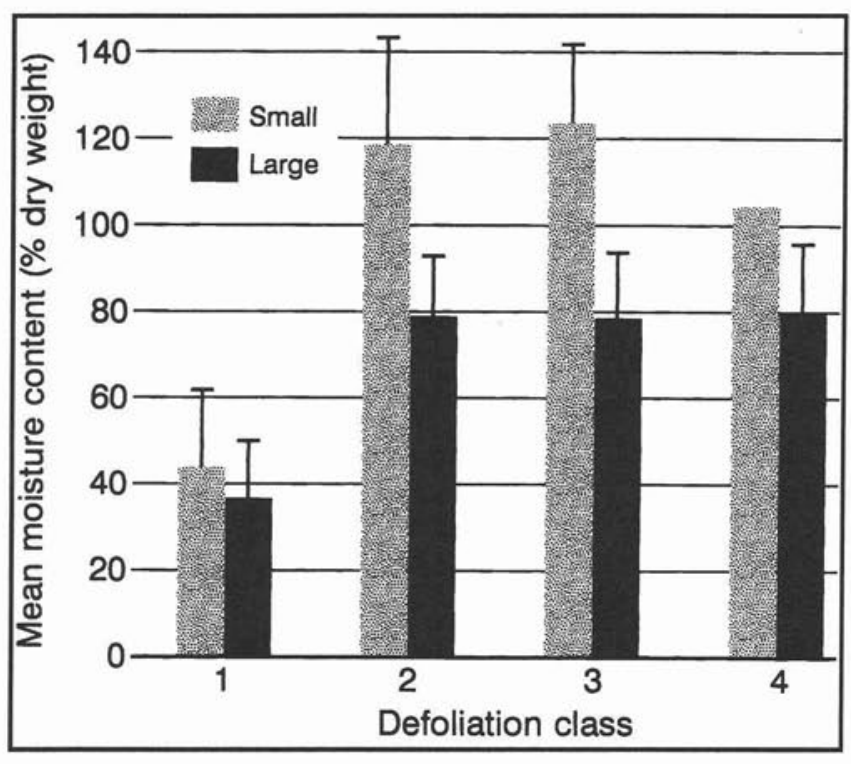

Fig. 1. Comparison of moisture content of defoliated white spruce by size and defoliation class.

\section{Dead Trees}

In logs from dead trees, MC was over $45 \%$ provided that the inner bark diameter was greater than $36 \mathrm{~cm}$, regardless of where this diameter occurred in the tree (Fig. 2). In logs less than $17 \mathrm{~cm}$ in diameter, the $\mathrm{MC}$ was nearly always less than $45 \%$. In the logs between 17 and $36 \mathrm{~cm}$ in diameter, the MC was unpredictable, ranging from $30 \%$ to $60 \%$. This variation was partly due to the skewed weight of the small trees; the bottom most logs of the small trees that fell into this diameter range had much higher MCs than the same diameter logs higher up from larger trees. Using the composite stem diagram (Fig. 2), the acceptability of logs in this size range can be assessed. Logs of diameter 17 to $36 \mathrm{~cm}$ (inner bark) from the base of dead trees will likely have at least $45 \% \mathrm{MC}$; the same size logs from upper sections of dead trees will likely have less than $45 \% \mathrm{MC}$.

\section{Heartwood: Sapwood and Height Variation}

Heartwood forms first in the lower tree stem resulting in lower wood MC near the ground. In live trees, the MC increases with height because of the decreasing proportion of heartwood to sapwood. In dead trees, the MC of the sapwood decreases with smaller diameter and greater height, so that the overall wood MC decreases with height (Barnes and Sinclair 1983).

Although overall MCs were acceptable, there were marked differences between sapwood MC and heartwood MC. Mean heartwood MC of all live trees was $46 \%$ vs. $144 \%$ in the sap- 


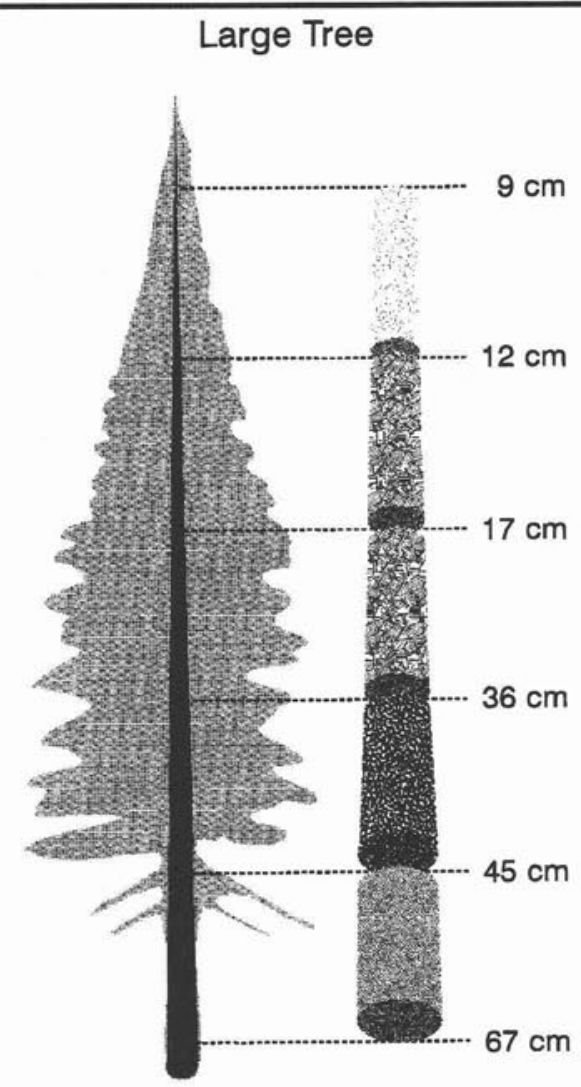

Average moisture content
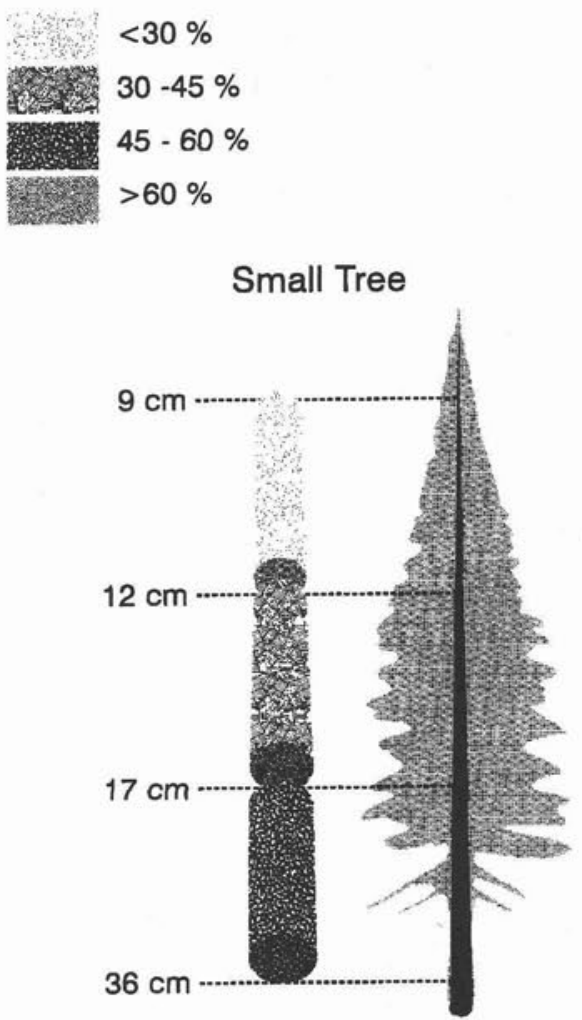

Note: All measurements refer to the diameter inside bark.

Fig. 2. Moisture content of logs from dead white spruce, according to diameter and size of tree. (MC was determined by volume weighted mean of dry weight moisture content from 145 sections for 27 randomly selected trees.)

wood. There are wide variations between sapwood and heartwood MC in spruce (Haygreen and Bowyer 1982). The largest trees will tend to have the lowest overall MCs because the heartwood proportion generally increases with the size of the tree. Operationally, this means that concentrations of large diameter logs going into the mill will result in "pockets" of low moisture fibre. The proportion of sapwood varies with vigour, age, and tree size (Hazenberg and Yang 1991; Lassen and Okkonen 1969), and the amount of foliage on the tree (Coyea and Margolis 1992). In pulp made from healthy trees, differences between sapwood and heartwood MC are probably unimportant because the pulp process homogenizes the heartwood and sapwood fibres. However, if defoliation reduces sapwood volume and/or sapwood MC, then pulp quality may be affected, based on the proportion of sapwood in the harvested timber.

The small dead trees $(<23 \mathrm{~cm}$ DBH $)$ had a higher average $\mathrm{MC}, 44 \%$, than the larger dead trees, $37 \%$. This moisture was concentrated almost entirely in the first 3-m section, whereas in the larger trees, the moisture was more uniformly distributed. Thus, it appears that stem sections to a diameter of approximately $36 \mathrm{~cm}$ of large white spruce, recently killed by spruce budworm, can be expected to contain enough moisture to meet the company's pulping requirements. Sections less than $17 \mathrm{~cm}$ in diameter from dead trees appear to be too dry unless they are the bottom most $\log$ in the tree.
Although the $\mathrm{H} / \mathrm{S}$ ratio appears to be the best predictor of MC, it is unavailable to the field forester when deciding whether or not to accept a budworm-killed (Defoliation Class 1) white spruce tree. These data suggest that an appropriate tree size criterion is $30 \mathrm{~cm} \mathrm{DBH}$ to ensure the dead trees have a minimum $45 \% \mathrm{MC}$ to a height of $5 \mathrm{~m}$. As a caution, however, Coyea and Margolis (1992) have shown DBH in balsam fir in Quebec to be less well correlated with foliage (leaf area) than various measures of sapwood area.

Moisture content of dead trees is strongly influenced by height. In budworm-killed balsam fir, $\mathrm{MC}$ ranged from about $50 \%$ to $150 \%$ over the length of the bole (Barnes and Sinclair 1983; Basham et al. 1974). Green heartwood MC in west coast species fluctuated with tree height while the sapwood MC remained fairly constant with height (Pong et al. 1986). The overall MC was $<45 \%$ in the sections above the height at which the diameter was $<30 \mathrm{~cm}$ in each of six trees and $>45 \%$ in the larger, lower sections. This indicates that the relationship of MC to height may be related to tree diameter. Although this observation could not be tested statistically, it may assist in selecting dead trees for harvest.

\section{Physical and Biological Implications of MC Variation}

Paper manufacturers are concerned about the possible effects of MC variation on volume and quality of fibre (Dolenko et al. 1981); however, the effects of a moisture decrease 
alone in dead wood are difficult to assess. Following the death of the tree, MC changes at different rates in sapwood vs. heartwood, and is associated with both sapwood and heartwood decay rates, effecting volume losses from $1.5 \%$ annually to $18 \%$ in some studies (Basham and Morawski 1964; Binotto and Locke 1981; van Raalte 1983b). Further variations are associated with tree height, notably in the upper sections of some insectdefoliated trees where $\mathrm{MC}$ falls below the decay threshold (Hinds et al. 1965).

Although no degrading organisms were found to be closely associated with defoliation in this study, some levels of decay in individual trees may still render wood unusable. Assessing decay should be considered when MC is suspected to be varying due to defoliation.

\section{Conclusion}

Moisture content in all surviving defoliated trees was sufficient for the mill's normal papermaking process. Dead trees generally contained insufficient moisture with the notable exception of the lower portions of stems, depending upon height and size.

\section{Acknowledgements}

This study was carried out under the auspices of the Forestry Branch, Manitoba Natural Resources. The authors thank Pine Falls Paper Company (formerly Abitibi-Price Inc.), Pine Falls, Manitoba, especially H. Peacock, L. Singbeil and "Pee Wee" Nault. We are grateful to Manitoba Natural Resources staff, especially L. Dunford, D. Kekish, T. Paton, M. Shariff and M. Tetrault, for their help; Dr. N. Holliday and G. Niznowski for statistics advice; and Dr. K.C. Yang and Dr. D.A. MacLean for reviewing early drafts.

\section{References}

Barnes, D.P. and S.A. Sinclair. 1983. Time-related changes in specific gravity and moisture content of spruce budworm killed balsam fir. Can. J. For. Res. 13: 257-263.

Basham, J.T. 1980. Preliminary report on the rate of deterioration of spruce budworm-killed balsam fir, and its relationship to secondary stem insects. Can. For. Serv., Sault Ste. Marie, ON. Inf. Rep. O-X314. 20 p.

Basham, J.T. and Z.J.R. Morawski. 1964. Cull studies. The defects and associated Basidiomycete fungi in the heartwood of living trees in the forests of Ontario. Dep. Forestry, Ottawa, ON. Publ. No. 1072.69 p.

Basham, J.T., D.E. Etheridge, J. Hudak, D. Lachance, L.P. Magasi and M.A. Stillwell. 1974. The deterioration of balsam fir trees killed by girdling in eastern Canada. Can. For. Serv., Sault Ste. Marie, ON. Inf. Rep. O-X-214. 48 p.

Binotto, A.P. and R.R. Locke. 1981. The impact of budworm damaged fir on pulp quality. Pulp Pap. Mag. Can. 82(1): 32-37.

Canadian Standards Association. 1986. Scaling roundwood: measurements of woodchips, tree residues, and byproducts. Canadian Standards Association, Rexdale, ON. 121 p.

Cerezke, H.F. and H.S. Gates. 1992. Forest insect and disease conditions in Alberta, Saskatchewan, Manitoba, and the Northwest Territories in 1991. For. Can., Northwest Reg., North. For. Cent., Edmonton, AB. Inf. Rep. NOR-X-325.

Coyea, M.R. and H.A. Margolis. 1992. Factors affecting the relationship between sapwood area and leaf area of balsam fir. Can. J. For. Res. 22: 1684-1693.
Dolenko, A.J., J.K. Shields, F.W. King, J.W. Roff and D. Ostaff. 1981. Wood protection. Chap. 8 pp. 177-224 in E. J. Mullins and T.S. McKnight (eds.). Canadian woods, their properties and uses. 3rd ed. University of Toronto Press, Toronto, ON.

Freese, F. 1967. Elementary statistical methods for foresters. For. Prod. Lab., USDA For. Serv., Madison, WI. Agric. Handbook No. 317.

Grammel, R.H., G. Becker, M. Gross and B. Höwecke. 1986. Einige Holzeigenschaften erkrankter Fichten und Tannen aus BadenWürttemberg, als Ergebnis einer flächendeckenden Erhebung. [Some wood properties of diseased spruce and fir from Baden-Württemberg as a result of an equal-area inquiry.] Hols als Roh- und Werkstoff 44: 287-292. [In German; English Summary.]

Haygreen, J.G. and J.L. Bowyer. 1982. Forest products and wood science, an introduction. Iowa State University Press, Ames, IA. 495 p.

Hazenberg, G. and K.C. Yang. 1991. The relationship of tree age with sapwood and heartwood width in black spruce, Picea mariana (Mill.) B.S.P. Holzforschung 45:317-320.

Hinds, T.E., F.G. Hawksworth and R.E. Davidson. 1965. Beetlekilled Engelmann spruce. Its deterioration in Colorado. J. For. 63(7): 536-542.

Husch, B., C.I. Miller and T.W. Beers. 1972. Forest mensuration. 2nd ed. Ronald Press, New York, NY. 410 p.

Kiil, A.D. 1968. Changes in the physical characteristics and moisture content of pine and spruce-fir slash during the first five years after logging. Can. Dep. For. Rural Dev., For. Res. Lab., Edmonton, AB. Intern. Rep. A-14. 40 p.

Knowles, K.R., D.S. Desrochers, R.A. Khan and A.R. Westwood. 1992. The impact of a spruce budworm infestation on forest production in eastem Manitoba. Proceedings of the Entomol. Soc. Manit. 48: 32-45. Lassen, L.E. and E.A. Okkonen. 1969. Sapwood thickness of Douglas-fir and five other western softwoods. USDA, For. Serv., U.S. For. Prod. Lab., Madison, WI. Res. Pap. FPL-124. 16 p.

Lowery, D.P., W.A. Hillstrom and E.E. Elert. 1977. Chipping and pulping dead trees of four Rocky Mountain timber species. USDA, For. Serv., Intermt. For. Range Exp. Stn., Ogden, UT. Res. Pap. INT193. 11p.

Moody, B.H. and H.F. Cerezke. 1985. Forest insect and disease conditions in Alberta, Saskatchewan, Manitoba, and the Northwest Territories in 1984 and predictions for 1985. Can. For. Serv., North. For. Res. Cent., Edmonton, AB. Inf. Rep. NOR-X-269.

Manitoba Natural Resources. 1989. Forest inventory field instruction manual. Man. Dep. Nat. Res., Forest Management Section, Winnipeg, MB. 85 p. (Unpubl. Doc.)

Parham, R.A. 1983. Wood physical properties. Chap. VII pp. 4654 in M.J. Kocurek and C.F.B. Stevens (eds.). Pulp and paper manufacture. Vol. 1. Properties of fibrous raw materials and their preparation for pulping. 3rd ed. Joint Textbook Committee of the Paper Industry (TAPPI, Atlanta, and CPPA, Montreal).

Pong, W.Y., D.R. Waddel and M.B. Lambert. 1986. Wood density - moisture profiles in old-growth Douglas-fir and western hemlock. USDA, For. Serv., Pac. Northwest For. Range Exp. Stn. Res. Pap. PNW-347. 30 p.

van Raalte, G.D. 1983a. Wood losses in mechanical debarking of spruce budworm killed balsam fir. Can. For. Serv., Fredericton, NB. Tech. Note No.79.

van Raalte, G.D. 1983b. Relationship between moisture content and wood decay in spruce budworm killed balsam fir. Can. For. Serv., Fredericton, NB. Tech. Note No. 104. 